\title{
Analisis Kemampuan Siswa Mengubah Representasi dalam Physics Problem Solving Pada Siswa SMA Kelas X
}

\author{
Nurhijrah N. Atjiang dan Darsikin \\ email : nurhijrah.atjiang@gmail.com \\ Program Studi Pendidikan Fisika FKIP Universitas Tadulako \\ Jl. Soekarno Hatta Km. 9 Kampus Bumi Tadulako Tondo Palu - Sulawesi Tengah
}

\begin{abstract}
Abstrak - Penelitian ini bertujuan untuk mendeskripsikan kemampuan siswa mengubah representasi dalam physics problem solving pada siswa SMA kelas X. Subyek penelitian ini terdiri dari 20 orang siswa dan dipilih 6 responden dengan cara pemberian tes pemilihan responden. Data diperoleh melalui pemberian tes pemilihan responden dan tes kemampuan representasi serta wawancara. Tes terdiri dari tiga nomor soal yang setiap soal terdiri dari dua pertanyaan yang diberikan kepada siswa melalui aktivitas thinking-aloud. Data penelitian dianalisis melalui pendekatan deskriptif-kualitatif. Hasil penelitian menunjukan bahwa kemampuan representasi siswa berbeda-beda dari setiap representasi yang diberikan.
\end{abstract}

Kata kunci: problem solving, kemampuan representasi

\section{PENDAHULUAN}

Banyak beranggapan bahwa fisika merupakan pelajaran yang sulit. Salah satu alasan fisika dikatakan pelajaran yang sulit karena fisika menuntut siswa untuk menguasai representasi-representasi berbeda (grafik, konseptual/keterangan lisan, rumus, gambar/diagram). Hal ini berarti siswa harus memiliki kemampuan berfikir, kemampuan bekerja, kemampuan bersikap ilmiah dan kemampuan memecahkan masalah sehingga siswa diharapkan memiliki kemampuan untuk merepresentasi suatu informasi dengan banyak cara [I]

Pada umumnya, siswa harus mempergunakan beberapa penyajian dalam memecahkan masalah fisika. Pembelajaran Fisika sering dianggap kurang menarik dan sulit dipahami sehingga berdampak pada kurangnya pemahaman konsep dan kemampuan memecahkan soal. Kesulitan tersebut dapat terjadi karena karakteristik materi pembelajaran Fisika yang abstrak, rumit, atau asing, serta menuntut kemampuan untuk menguasai dan mengelola perubahan diantara representasi-representasi yang berbeda. Representasi yang paling sering digunakan oleh guru adalah representasi matematis sehingga representasi lainnya sering terabaikan [2].

Keterampilan siswa menggunakan representasi adalah hal yang penting untuk diketahui karena dapat menjadi evaluasi terhadap kinerja guru dan juga ketika membuat soal ujian. Dari hasil evaluasi tersebut seorang guru dapat merencanakan pertanyaan- pertanyaan yang tepat. Seorang guru dapat membuat pertanyaan-pertanyaan yang lebih bervariasi untuk menggali pemahaman siswa.

Multiple representasi dianggap kunci untuk belajar fisika sehingga ada motivasi yang cukup baik untuk mempelajari bagaimana siswa menggunakan multiple representasi saat memecahkan masalah dan belajar bagaimana cara terbaik untuk mengajarkan pemecahan masalah dengan menggunakan multiple representasi [3].

Pemberian soal-soal latihan atau ujian dan tugas yang tergolong sulit dapat meningkatkan kemampuan representasi siswa, karena dalam soal yang tergolong sulit tersebut siswa dituntut untuk mengerahkan semua kemampuan yang dimilikinya sehingga siswa dapat menyelesaikan soal-soal fisika dengan sukses dan hasil belajar siswa dapat mengalami peningkatan [4].

Tahap terpentig dari problem solving adalah menentukan pokok dari permasalahan yang akan dipecahkan agar siswa dapat lebih fokus dalam menyelesaikan masalah yang sedang dihadapi. Karakteristik dalam melakukan representasi sangat berpengaruh terhadap problem solving karena setiap siswa dapat menyelesaikan atau menentukan tujuan permasalahan agar dapat mengetahui langkah awal yang akan dilakukan untuk fokus menyelesaikan masalah representasi yang diberikan.

\section{METODE PENELITIAN}

Penelitian ini menggunakan pendekatan deskriptif-kualitatif yang datanya berupa faktafakta yang ada. Subyek dalam penelitian adalah 
20 siswa kelas $X$ IPA sebuah SMA negeri di Kota Palu. Subyek penelitian terdiri atas 6 (enam) orang siswa berdasarkan skor jawaban tes pemilihan responden untuk mengerjakan tes kemampuan representasi dan wawancara mendalam.

Sebanyak 3 butir soal tes pemilihan responden diberikan kepada 25 siswa. Sebanyak 3 butir soal tes kemampuan representasi dengan materi Gerak Lurus sebagai konteks soal.

Berdasarkan data dari tes pemilihan responden, dihitung skor rata-rata dan standar deviasi. Skor-skor tersebut dikelompokkan untuk berdasarkan kategori tinggi, sedang dan rendah.

Berdasarkan hasil penelitian dan analisis data, diperoleh skor jawaban tes pemilihan responden dari tiap siswa disajikan dalam Tabel 1.

Berdasarkan pengolahan data, diperoleh skor rata-rata adalah 33,20 dan nilai standar deviasi 8,18.

Tabel 1 Skor Jawaban Tes Pemilihan Responden

\begin{tabular}{|c|c|c|}
\hline $\begin{array}{c}\text { Inisial } \\
\text { Responden }\end{array}$ & Skor & Kategori \\
\hline R-01 & 28 & Rendah \\
\hline R-02 & 28 & Rendah \\
\hline R-03 & 24 & Rendah \\
\hline R-04 & 28 & Rendah \\
\hline R-05 & 32 & Rendah \\
\hline R-06 & 28 & Rendah \\
\hline R-07 & 52 & Tinggi \\
\hline R-08 & 28 & Rendah \\
\hline R-09 & 28 & Rendah \\
\hline R-10 & 52 & Tinggi \\
\hline R-11 & 52 & Tinggi \\
\hline R-12 & 44 & Tinggi \\
\hline R-13 & 28 & Rendah \\
\hline R-14 & 40 & Sedang \\
\hline R-15 & 24 & Rendah \\
\hline R-16 & 36 & Rendah \\
\hline R-14 & 40 & Sedang \\
\hline R-18 & 32 & Rendah \\
\hline R-19 & 28 & Rendah \\
\hline R-20 & 28 & Rendah \\
\hline
\end{tabular}

Responden yang terpilih untuk terlibat tes thinking-aloud dan wawancara berdasarkan kategori adalah sebanyak 6 orang responden yakni:
1) Kategori tinggi: R-10 dan R-11
2) Kategori sedang: $R-14$ dan $R-17$
3) Kategori rendah: R-08 dan R-19

\section{HASIL PENELITIAN DAN PEMBAHASAN}

Siswa harus memiliki kemampuan representasi agar dapat membantu siswa dalam memecahkan masalah. Kemampuan representasi merupakan sesuatu yang dapat dilakukan siswa untuk menggambarkan suatu bentuk representasi ke bentuk representasi yang lain. Dengan kata lain, siswa dapat mengubah bentuk representasi yang telah diberikan kebentuk representasi yang ditanyakan. Misalnya, representasi grafik diadopsi ke dalam bentuk representasi verbal, gambar, matematis dan yang lainnya. Representasi yang dibuat oleh siswa merupakan ungkapan-ungkapan dari ide-ide yang ditampilkan siswa dalam upayanya mencari suatu solusi dari masalah yang dihadapinya. Penelitian ini menitikberatkan pada kemampuan siswa mengubah representasi physics problem solving.

\section{a) Kemampuan Siswa Mengubah Representasi}

Setiap siswa mempunyai cara yang berbeda untuk mengkontruksikan pengetahuannya. Dalam hal ini, sangat memungkinkan bagi siswa untuk mencoba berbagai macam representasi dalam menyelesaikan suatu masalah. Berikut disjikan deskriptif tentang kemampuan siswa mengubah representasi dalam physics problem solving.

\section{$>$ Representasi Grafik ke Verbal}

Representasi grafik ke verbal dijadikan soal Nomor 1 yaitu siswa diminta untuk mengubah representasi grafik yang diberikan ke representasi verbal yang diharapkan.

Transkrip thinking-aloud R-10 Soal Nomor $1 \mathrm{a}$

$<\ldots>$

Soalnya tentang penjelasan singkat gerak sebuah benda

$<\ldots>$

Yang saya pikirkan benda pertama lebih cepat perpindahannya daripada benda kedua karena karena benda pertama menempuh jarak $1 \mathrm{~m}$ dengan waktu $6 \mathrm{~s}$ sedangkan benda kedua menempuh jarak $7 \mathrm{~m}$ dengan waktu $4 \mathrm{~s}$. Disoal ini tidak ada yang diketahui Cuma yang ada grafik dan dijelaskan.

Untuk soal Nomor 1a, R-10 tidak langsung menjawab R-10 menganalisis hal-hal yang diketahui dan yang ditanyakan pada soal kemudian membuat catatan-catatan kecil sebelum menjawab soal di lembar jawaban yang telah disediakan. Pada saat R-10 mengerjakan soal Nomor $1 a$, ia sulit 
menentukan yang mana sumbu untuk jarak dan mana sumbu untuk waktu. Saat mengerjakan soal ini R-10 membutuhkan banyak waktu untuk menyelesaikannya.

Transkip thinking-aloud R-14 Soal Nomor $1 b$

$<\ldots>$

Dilihat dari waktunya dan perpindahannya. Dilihat dari berapa lama berpindahnya suatu benda.

Pada saat mengerjakan soal ini, R-14 langsung menjawab tanpa harus memikirkan hal-hal yang diketahui dalam soal sehingga jawaban yang dia tuliskan pada lembar jawabannya adalah jawaban yang terlintas dalam pikirannya setelah dia membaca soal.

Untuk soal Nomor 1 siswa diberikan representasi grafik kemudian mereka diperintahkan untuk mengubah representasi tersebut ke dalam representasi verbal. Dari transkrip di atas dapat dilihat kemampuan R-10 dapat menjelaskan representasi grafik ke representasi verbal untuk soal Nomor 1 a sangat baik. Sebelum siswa tersebut menjawab soal $1 a$ siswa tersebut menganalisis dengan baik grafik tersebut baru menjawab apa yang ditanyakan, sedangkan untuk R-14 kemampuan untuk menjelakan representasi grafik ke representasi verbal sangat kurang karena ia menjawab soal tanpa menganalisis hal-hal yang diketahui pada soal. Pada soal ini terutama soal Nomor $1 b$ hampir semua siswa menjawab salah karena siswa kurang mengerti maksud dari pertanyaan pada soal rsebut. Oleh karena itu, siswa menjawab hampir sama dengan jawaban yang mereka tuliskan pada soal Nomor 1a. Beragam jawaban yang diberikan siswa menunjukan bahwa siswa kurang memahami materi dan pengetahuan mereka tentang menterjemahkan representasi grafik ke representasi verbal sangat kurang karena banyak siswa yang mengatakan soal seperti ini baru kali ini diberikan. Gambar 1 adalah kutipan jawaban R-10 soal Nomor 1a dan Gambar 2 adalah kutipan jawaban R-14 soal Nomor $1 \mathrm{~b}$.

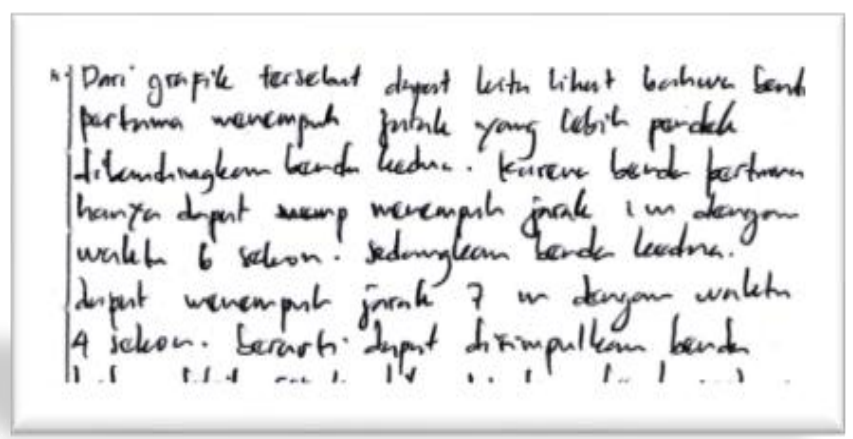

Gambar 1. Kutipan jawaban R-10 untuk soal Nomor 1a

\section{b.) chli hat dari berapa lama berbindh nya suatu benda.}

Gambar 2. Kutipan jawaban R-14 untuk soal Nomor 1b

Hasil wawancara juga memperjelas bahwa R-14 dan R-10 berbeda ketika mereka mengerjakan soal. Berikut kutipan wawancaranya:

Peneliti : Coba lihat soal Nomor 1. Soalnya itukan grafik terus disuruh menjelaskan, sebelum kamu mejawab soal itu apakah kamu memikirkan konsepnya terlebih dahulu atau hanya melihat hal-hal yang diketahui dalam soal?

R-14 : Saya hanya melihat hal-hal yang ada dalam soal. Contohnya seperti grafiknya itu. Grafiknya itu sudah menjelaskan bagaimana atau menjelaskan sesuatu yang diminta oleh soal.

Peneliti : Coba lihat soal Nomor 1. Soalnya itukan grafik terus disuruh menjelaskan, sebelum kamu mejawab soal itu apakah kamu memikirkan konsepnya terlebih dahulu atau hanya melihat hal-hal yang diketahui dalam soal?

R-10 : Memikirkan konsepnya terlebih dahulu.

Hasil penelitian yang dilakukan ini sesuai dengan penelitian yang dilakukan oleh [5] yang menggunakan instrumen soal uraian yang menunjukan bahwa kemampuan representasi siswa dalam mentransformasikan representasi verbal ke representasi grafik sangat rendah.

\section{> Representasi Verbal ke Grafik dan Matematis}

Representasi verbal ke representasi grafik dan matematis dijadikan soal Nomor 2. Pada soal ini siswa diminta untuk mengubah representasi verbal kedalam dua bentuk representasi yaitu representasi grafik dan representasi matematis. Pada soal ini siswa diberikan tiga pertanyaan agar dapat memakili semua aspek yang diharapkan.

Transkrip thinking-aloud R-11 Soal Nomor 2a

$<\ldots>$

Kecepatan terhadap waktu. Jadi, pada sumbu $Y$ kecepatan sedangkan pada sumbu $X$ eee akan dinyatakan waktu. Kemudian mengalami percepatan dari keadaan diam nol sampai mencapai kecepatan lima belas meter per sekon selama enam sekon. Jadi, kecepatan lima belas meter per sekon pada waktu enam sekon ok. 
Kemudian mobil bertahan dengan kecepatan ini berarti kecepatan lima belas selama enam sekon. Mobil bertahan selama dua puluh sekon, berarti enam sitambah dua puluh sama dengan dua puluh enam disini. Masih pada kecepatan lima belas meter per sekon ok. Habis itu, dan dengan menginjak rem mobil diperlambat dala, selang waktu sepuluh sekon, berarti sampai pada eee tiga puluh enam sekon.

Pada saat mengerjakan soal Nomor 2a representasi verbal ke representasi grafik $\mathrm{R}-11$ mampu menjawab dengan benar apa yang ditanyakan pada soal dibandingkan dengan siswa yang lain. Dari hasil jawaban yang diberikan dapat dilihat bahwa R-11 merupakan responden yang memiliki kemapuan tinggi dalam menjabarkan representasi verbal ke representasi grafik.

Transkrip thinking-aloud R-17 Soal Nomor 2b (percepatan mobil)

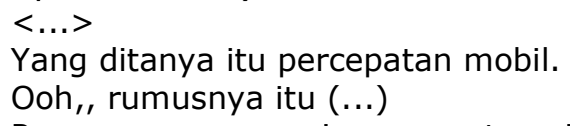
dengan delta $v$ per delta $t$. Delta $v$ itu kecepatan akhir dikurang kecepatan awal, delta $t$ itu waktu akhir dikurang waktu awal. Lima belas dikurang nol per tiga puluh enam dikurang enam sama dengan lima belas perr tiga puluh sama dengan nol koma lima meter per sekon.

Untuk soal Nomor 2b yaitu representasi verbal ke representasi matematis terdapat dua sub soal yaitu percepatan mobil dan perlambatan mobil. Pada saat mengerjakan soal percepatan mobil R-17 hanya menuliskan persamaan matematisnya menggunakan konteks permasalahan pada grafik yang R-17 tuliskan pada jawaban soal Nomor 2a.

Kemampuan representasi $\mathrm{R}-17$ pada saat mengerjakan soal ini sangat kurang dapat dilihat dari hasil jawaban yang ia berikan, R-17 hanya dapat menuliskan persamaannya dengan benar tetapi penyelesaian soalnya salah.

Transkrip thinking-aloud R-19 Soal Nomor 2b (perlambatan mobil)

\section{$<\ldots>$}

Untuk a tiga perlambatn $v$ tiga per $t$ tiga sama dengan lima belas per sepuluh sama dengan satu koma lima meter per sekon pangkat dua.

Untuk soal Nomor $2 \mathrm{~b}$ tentang perlambatan mobil, pada saat R-19 mengerjakan soal ini R19 hanya dapat menyelesaikan jawaban akhir dengan benar tetapi persamaan matematisnya dan langkah penyelesaian yang digunakan salah.

Untuk soal ini, $\mathrm{R}-17$ bingung dalam mengerjakannya terutama pada saat ketika ia sudah selesai menuliskan rumusnya $\mathrm{R}-17$ susah untuk melanjutkan apa yang harus dia lakukan. Untuk R-19, jawaban yang diberikan benar tetapi langkah-langkah dalam mengerjakan soalnya salah karena ketika R-19 menuliskan rumusnya R-19 hanya melihat apa yang diketahui pada soal.

Dari transkrip di atas dapat dilihat kemampuan representasi $\mathrm{R}-11$ dalam mengubah representasi verbal ke grafik sangat baik sehingga pada saat mengerjakan soal Nomor 2a siswa tersebut menjelaskan dengan sangat baik.

Untuk soal Nomor 2b untuk percepatan mobil R-17 dapat menuliskan rumusnya tetapi cara penyelesaiannya dan hasil yang diperoleh kurang tepat sedangkan untuk soal Nomor $2 \mathrm{~b}$ perlambatan mobil R-19 dapat menuliskan hasilnya dengan benar tetapi rumus dan cara penyelesaiannya kurang tepat. Gambar 3 adalah kutipan jawaban R-11, Gambar 4 adalah kutipan jawaban R-17 dan Gambar 5 adalah kutipan jawaban $\mathrm{R}-19$.

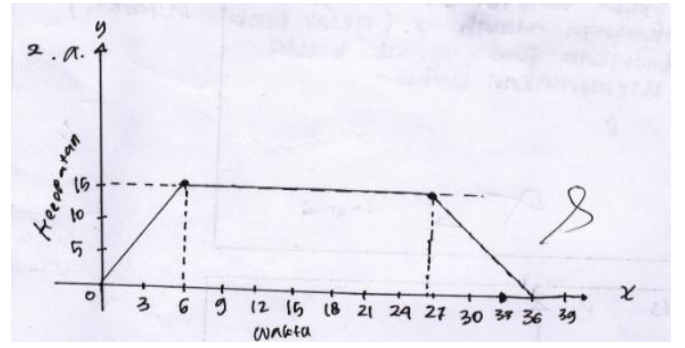

Gambar 3. Kutipan jawaban R-11 untuk soal Nomor 2a

$$
\begin{aligned}
& \text { b). pereepatan mobil } \\
& \text { (i). } a=\frac{\Delta V}{\Delta t}=\frac{v \text { akhir }-v \text { awal }}{t \text { akhir - akual }} \\
& =\frac{15-0}{36-6} \\
& =\frac{15}{30} \\
& =0.8 \mathrm{~m} / \mathrm{s} \text {. }
\end{aligned}
$$

Gambar 4. Kutipan jawaban R-17 untuk soal Nomor 2b (percepatan mobil

$$
\begin{aligned}
a_{3} & =\frac{v_{3}}{t_{3}} \\
& =\frac{15}{10}=1,5^{\mathrm{m}} / \mathrm{s}^{2}
\end{aligned}
$$

Gambar 5. Kutipan jawaban R-19 untuk soal Nomor 2b (perlambatan mobil)

Hasil wawancara ada beberapa siswa menyatakan bahwa mereka menjawab soal berdasarkan apa yang mereka lihat tanpa 
menganalisis soal itu terlebih dahulu. Menurut mereka soal seperti ini baru mereka dapatkan sehingga mereka memiliki kesulitan untuk mengerjakan soal tersebut. Berikut kutipan wawancaranya.

Peneliti : Bagaimana caranya kamu menggambar grafik pada soal Nomor 2?

R-17 : Caranya? Ya digambar. Maksudnya?

Peneliti : Bagaimana kamu mengetahui kalau gambarnya seperti itu?

R-17 : Dari dia punya nilai, dia punya soal.

Peneliti : Apakah soal seperti ini baru kamu dapatkan?

R-17 : Iya baru.

Peneliti : Bagaimana cara anda mengerjakan grafik seperti ini, apa yang anda pikirkan?

R-19 : Awalnya dicari rumusnya terus dikerjakan dulu terus membuat grafiknya.

Peneliti : Soal Nomor 2b, bagaimana kamu mengetahui rumusnya seperti itu?

R-19 : Karena yang diketahui ada waktu dan kecepatan

Peneliti : Lihat soal Nomor 2, grafiknya kamu gambar tidak?

R-11 : Gambar.

Peneliti : Apakah soal seperti ini baru kamu dapatkan?

R-11 : Iya, kalau saya baru saya dapatkan.

Kemampuan siswa dalam mengubah representasi verbal ke representasi grafik memiliki kategori tinggi. Karakteristik soal yang sulit memungkinkan siswa menggunakan banyak representasi hal ini disebabkan pada soal yang sulit siswa tidak hanya mampu menebak dan mengandalkan hafalan yang mereka telah hafalkan sebelumnya melainkan membutuhkan usaha dengan merepresnetasikan konsep secara terstruktur untuk memperoleh jawaban akhir yang diharapkan [2].

\section{Representasi Verbal ke Matematis}

Representasi verbal ke matematis dijadikan soal Nomor 3. Pada soal ini siswa diminta untuk mengubah representasi verbal (yang diberikan) ke representasi matematis (yang diharapkan). Pada soal ini siswa diberi dua pertanyaan untuk mengukur seberapa besar kemampuan yang dimiliki oleh siswa dalam mengubah representasi tersebut. Menurut sumber atau beberapa penelitian sebelumnya banyak siswa yang memiliki kesulitan dalam mengubah representasi apapun ke dalam representasi matematis karena representasi matematis membutuhkan banyak latihan soal agar memudahkan siswa ketika mengerjakan soal yang diberikan.

Transkrip thinking-aloud R-08 Soal Nomor 3a

$$
<\ldots>
$$

Diketahui $v$ sama dengan sepuluh meter per sekon dengan a sama dengan satu koma lima meter per sekon pangkat dua. Vt sama dengan kecepatan awal ditambah a dikali waktu. Sepuluh ditambah satu koma lima dikali sepuluh. Satu koma lima dikali sepuluh kemudian ditambah sepuluh sama dengan dua puluh lima.

Transkrip thinking-aloud R-11 Soal Nomor 3b $<\ldots>$

$v t$ sama dengan vo ditambah dua dikali as sama dengan sepuluh meter per sekon ditambah dua dikali satu koma lima dikali seratus. Jadi sepuluh tambah tiga ratus sadma dengan tiga ratus sepuluh meter per sekon.

Dari transkrip di atas dapat dilihat bahwa kemampuan yang dimiliki R-08 dalam menyelesaikan soal Nomor $3 a$ sangat baik dibandingakn siswa yang lain. Dari semua siswa hanya R-08 yang dapat menuliskan rumus dengan benar dan dapat menyelesaikan soal Nomor $3 a$ dengan benar, sedangkan untuk soal Nomor 3b, pada saat mengerjakan soal R-11 salah menggunakan rumus sehingga jawaban yang dihasilkan salah. Berikut kutipan jawab Gambar 6 adalah kutipan jawaban R-08 dan Gambar 7 adalah kutipan jawaban R-11.

$$
\begin{aligned}
& \text { 3. Dik: } V=10 \mathrm{~m} / \mathrm{s} \quad a=1,5 \mathrm{~m} / \mathrm{s}^{2} \\
& \text { Dit: a. } v \\
& \text { Penye: at } V_{t}=V_{0}+a \cdot t \\
& =10+(1,5 \times 10) \\
& =20015 \\
& =0 \in \mathrm{m} / \mathrm{c}
\end{aligned}
$$

Gambar 6. Kutipan jawaban R-08 untuk soal Nomor 3a

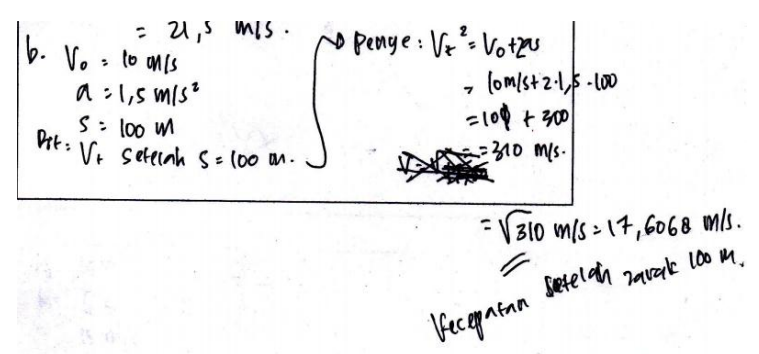

Gambar 7 Kutipan jawaban R-11 untuk soal Nomor 3b

Pada saat wawancara ada beberapa siswa menyatakan bahwa mereka kurang mengetahui simbol-simbol fisika sehingga mereka kesulitan untuk menentukan rumus apa yang digunakan 
pada saat mengerjakan soal yang memerlukan perhitungan. Berikut kutipan wancaranya:

Peneliti : Menurut kamu lebih mudah mengerjakan soal yang menggunakan angka-angka atau menggunakan simbolsimbol?

R-14 : Saya menggunakan angka-angka karena saya tidak terlalu hafal simbolsimbolnya.

Peneliti : Menurut kamu lebih mudah mengerjakan soal yang menggunakan angka-angka atau menggunakan simbolsimbol?

R-17 : Menggunakan angka-angka karena saya tidak tau simbolnya.

Peneliti : Menurut kamu lebih mudah mengerjakan soal yang menggunakan angka-angka atau menggunakan simbolsimbol?

R-19 : Simbol.

Peneliti : Kenapa?

R-19 : Karena kita harus mengetahui simbol itu simbol apa.

Peneliti : Berarti kalian disini banyak yang belum mengetahui simbol-simbol dalam fisika?

R-19 : Iya.

Penelitian yang menggunakan soal Pilihan Ganda pada materi Hukum Newton menunjukan bahwa representasi matematis memiliki nilai paling rendah dibandingkan dengan representasi lain. Hal ini disebabkan karena siswa kurang memahami persaman atau rumus dalam fisika. Ketika mereka memecahkan masalah fisika, mereka menggunakan masalah untuk menemukan persamaan dalam menghitung jawaban tetapi mereka kurang memahami masalah pada fisika [5].

\section{b) Persentase Kemampuan Representasi dan Skor Rata-Rata Siswa}

Berdasarkan hasil dari pemberian tes kemampuan representasi dengan cara thinkingaloud dan penjelasan di atas diperoleh persentase kemampuan representasi dan skor rata-rata masing-masing siswa dapat dilihat pada tabel berikut.

Dari hasil analisis yang dilakukan pada saat siswa menjawab soal melalui kegiatan thinkingaloud dan melihat hasil jawaban siswa yang mereka tuliskan dapat dilihat bahwa kemampuan representasi yang dimiliki oleh setiap siswa berbeda-beda. Ada siswa yang dapat mengubah representasi grafik ke verbal, verbal ke grafik dan verbal ke matematis tetapi dari ketiga representasi yang diberikan kemudian diubah ke dalam representasi yang diharapkan, representasi verbal ke matematislah yang kurang dikuasai atau dimengerti oleh siswa.

Berdasarkan hasil dari pemberian tes kemampuan representasi dengan cara thinkingaloud dan penjelasan di atas diperoleh persentase kemampuan representasi dan skor rata-rata masing-masing siswa dapat dilihat pada Tabel 2.

Tabel 2 Persentasi Kemampuan Representasi siswa

\begin{tabular}{|c|c|c|c|c|c|c|}
\hline \multirow{3}{*}{$\begin{array}{l}N \\
o\end{array}$} & \multirow{3}{*}{$\begin{array}{l}\text { Inisial } \\
\text { Siswa }\end{array}$} & \multicolumn{3}{|c|}{ Nomor Soal } & \multirow{3}{*}{$\begin{array}{l}\text { Jumlah } \\
(\%)\end{array}$} & \multirow{3}{*}{$\begin{array}{l}\text { Kategor } \\
\mathrm{i}\end{array}$} \\
\hline & & 1 & 2 & 3 & & \\
\hline & & 5 & 5 & 5 & & \\
\hline 1 & $R-14$ & 3,00 & 3,00 & 3,00 & 60,00 & Cukup \\
\hline 2 & $\mathrm{R}-17$ & 2,00 & 3,00 & 2,00 & 46,67 & Kurang \\
\hline 3 & $R-08$ & 3,00 & 2,00 & 4,00 & 60,00 & Cukup \\
\hline 4 & $R-19$ & 2,00 & 3,00 & 2,00 & 46,67 & Kurang \\
\hline 5 & $\mathrm{R}-10$ & 4,00 & 4,00 & 3,00 & 73,33 & Baik \\
\hline 6 & $\mathrm{R}-11$ & 4,00 & 4,00 & 4,00 & 80,00 & Baik \\
\hline
\end{tabular}

Dari Tabel 2 dapat dilihat persentase kemampuan representasi yang dimiliki siswa berbeda-beda dalam menjawab soal yang diberikan. Dari tabel di atas dapat dilihat bahwa hanya R-10 dan R-11 yang dapat dapat mengubah representasi dengan baik, $\mathrm{R}-14$ dan R-08 kemampuan representasi yang mereka miliki sama sedangkan R-17 dan R-19 kemampuan representasi yang mereka miliki rendah dibandingkan dengan siswa yang lainnya. Perbandingan kemampuan representasi masing-masing siswa dapat dilihat pada Gambar 8.

Tabel 2 menggambarkan kemampuan representasi siswa yang dilihat melalui kegiatan thinking-aloud dan hasil jawaban yang mereka tuliskan sedangkan setelah digabungkan dengan kemampuan yang dimiliki siswa dalam memecahkan masalah dapat dilihat pada Tabel 3.

Tabel 3 Skor Rata-Rata Siswa

\begin{tabular}{|c|c|c|c|c|c|c|}
\hline \multirow{3}{*}{$\begin{array}{l}\mathrm{N} \\
\mathrm{O}\end{array}$} & \multirow{3}{*}{$\begin{array}{l}\text { Inisial } \\
\text { Siswa }\end{array}$} & \multicolumn{3}{|c|}{ Nomor Butir Soal } & \multirow{3}{*}{$\begin{array}{l}\text { Skor } \\
\text { rata- } \\
\text { rata } \\
(\%)\end{array}$} & \multirow{3}{*}{$\begin{array}{l}\text { Kategori } \\
\text { berdasar } \\
\text { kan } \\
\text { Depdikna } \\
\mathrm{s}\end{array}$} \\
\hline & & \multirow{2}{*}{\begin{tabular}{|l|}
1 \\
1 \\
\end{tabular}} & \multirow{2}{*}{\begin{tabular}{|l|}
2 \\
15
\end{tabular}} & \multirow{2}{*}{$\begin{array}{l}3 \\
10\end{array}$} & & \\
\hline & & & & & & \\
\hline 1 & $\mathrm{R}-11$ & 9 & 11 & 6 & 74,28 & Baik \\
\hline 2 & $R-10$ & 9 & 12 & 5 & 74,28 & Baik \\
\hline 3 & $\mathrm{R}-14$ & 6 & 6 & 5 & 48,57 & Kurang \\
\hline 4 & $\mathrm{R}-17$ & 4 & 8 & 4 & 45,71 & Kurang \\
\hline 5 & $\mathrm{R}-08$ & 5 & 5 & 8 & 51,42 & Kurang \\
\hline 6 & $\mathrm{R}-19$ & 4 & 11 & 4 & 54,28 & Kurang \\
\hline \multicolumn{2}{|c|}{$\Sigma$ Nilai } & 37 & 53 & 32 & & \\
\hline \multicolumn{2}{|c|}{$\begin{array}{l}\text { Skor } \\
\text { Maksimal }\end{array}$} & 60 & 90 & 60 & & \\
\hline
\end{tabular}

Tabel 3 menunjukan skor rata-rata setiap siswa dapat kita lihat dari hasil penggabungan 
jawaban dan penjelasan yang diberikan siswa. Dari hasil analisis dapat dilihat bahwa responden $\mathrm{R}-11$ dan $\mathrm{R}-10$ memperoleh kategori baik sedangkan untuk R-14, R-17, R-08 dan R19 memperoleh kategori tinggi rendah. Untuk lebih jelasnya, berikut disajikan diagram perolehan skor rata-rata siswa per butir soal.

Dari hasil penjelasan di atas dapat dilihat bahwa kemampuan representasi siswa dari ketiga representasi yang ditawarkan, representasi matematis yang meperoleh kategori rendah. Hal ini disebabkan oleh pada saat kegiatan pembelajaran berlangsung guru tidak menjelaskan secara keseluruhan materi yang diberikan tetapi hanya memberikan tugas kemudian siswa yang menjawab tanpa adanya bimbingan dari guru mata pelajaran tersebut.

\section{KESIMPULAN}

Berdasarkan analisis data penelitian maka dapat ditarik kesimpulan sebagai berikut:

1. Kemampuan mengubah representasi dalam memecahakan masalah fisika yang dimiliki oleh siswa masih kurang, dapat dilihat dari semua soal yang diberikan hanya beberapa siswa yang dapat menjelaskan sesuai apa yang diharapkan.

2. Kurangnya pemahaman dalam memecahkan masalah membuat siswa kesulitan dalam mengubah representasi.

\section{DAFTAR PUSTAKA}

[1] Etkina et al. (2006). "An Averview of Recent Research On Multirepresentasi". International Journal of Science Education.

[2] Deliana, E. (2012). Kemampuan Multi Representasi Siswa dalam Menjawab Soal Tes Uraian Materi Cermin Lengkung Di SMP. Skripsi Pada FPS UPI Bandung: Tidak Diterbitkan. [online]

Tersedia:http://www.repository.edu.upi.pdf. [18 Desember 2012]

[3] Kohl, P.B. (2007). Affects of Representation On Students Solving Problem: A Fine: Graided Characterization Physical Review Special TopicsPhysics Education Research.

[4] Waldrip, B and Prain, V. (2006). "An Exploratory Study of Teachers' and Students' Use of Multimodal Representations of Concepts in primary Science". International Journal of Science Education.

[5] Rosengrant, D. (2007). Multiple Representations and Free-Body Diagrams Do Students Benefit From Using Them. Disertasi Doktor pada State Univerisity of Jersey. [On Line]. Tersedia: http://science.kennesaw.edu/ drosengr/Rosengra nt Dissertation.pdf. [20 september 2013] 